\title{
GERAKAN PEMBAHARUAN PEMIKIRAN ISLAM DI INDONESIA
}

\author{
Suaidi Asyari \\ Fakultas Ushuluddin IAIN Sulthan Thaha Saifuddin \\ Jl. Arif Rahman Hakim Telanaipura, Jambi, 36124 \\ e-mail: sudi531@yahoo.co.uk.
}

\begin{abstract}
Abstrak: Cepatnya perubahan yang terjadi di tengah kehidupan sosial kemasyarakatan di era globalisasi ini seringkali tidak seimbang dengan upaya pembaharuan pemikiran di kalangan umat Islam. Tampaknya, hal ini disebabkan oleh keyakinan bahwa karyakarya pemikiran ulama masa lalu dianggap sakral, sudah menjawab setiap tantangan yang ada sepanjang sejarah umat Islam dan karena itu dianggap final. Karenanya, setiap upaya untuk mengkritisinya dianggap sebagai "makar akademis" dan pelakunya bahkan dapat dituduh murtad. Akhirnya, timbul kekhawatiran di kalangan praktisi akademis untuk melakukan pembaharuan yang berakibat pada stagnasi pemikiran. Tulisan ini adalah sebuah upaya untuk mendiskusikan problem-problem pembaruan pemikiran Islam di Indonesia lebih detail dan upaya-upaya solutif terhadap problemproblem tersebut.
\end{abstract}

Abstract: Islamic Thought Reform Movement in Indonesia: From Part of Problem to be Part of Solution. The rapid development of social life in the era of globalization has often been run unparallel with the effort for thinking reform within the Muslim community. It appears that this may have arisen from the belief that the works of the past scholars of Islam are regarded to be sacred, capable of responding to any challenges in the span of the history of Muslim community and thus regarded final. Similarly, any attempt to criticize such views is seen as an academic assault the actor of whom may be accused of doing an act of apostasy. At the end, this lead to anxiety within the academicians to carry out reform that would have a logical consequence of thinking to be stagnant. This essay is an attemp to discuss the problems of Islamic thought reform in Indonesia in details as well as find solution to such problems.

Kata Kunci: pembaharuan pemikiran Islam, Indonesia

\section{Pendahuluan}

Beberapa tahun terakhir ini telah terjadi kelesuan pembaharuan pemikiran Islam di Indonesia yang luar biasa. Para aktivis pembaharu terlihat sangat khawatir untuk mengemukakan gagasan barunya. Tulisan-tulisan di media masa berkaitan dengan pembaharuan 
sudah jarang muncul. ${ }^{1}$ Diskusi-diskusi hanya dilakukan di ruang terbatas dan monolog serta homogen. Meskipun di sana sini terlihat ada gejala pemikiran umat Islam tertentu yang muncul melalui media khutbah misalnya, tetapi terkesan berjalan di tempat atau bahkan mundur beberapa langkah. Upaya kelembagaan juga dilakukan seperti apa yang dilakukan apa yang dilakukan oleh Kementerian Agama melalui Annual Conference of Islamic Studies. ${ }^{2}$ Tetapi hal ini pun tidak luput dari tantangan yang disebutkan di atas. Salah satu contohnya adalah gagalnya Nasr Abu Zayd untuk menghadiri acara penting tersebut ketika dilaksanakan di Riau dan pada seminar internasional Islam, Democracy and Good Governance in Indonesia yang dilakasanakan oleh IAIN Riau pada tanggal 21-24 November 2007 dan Seminar Internasional dengan tema Muslim Intelectuals as Agents of Change oleh UNISMA Malang pada tanggal 27-29 November 2007 di Batu Malang. Pada saat itu, dari berbagai media diketahui bahwa penyebab gagalnya Nasr Abu Zayd menghadiri kedua acara tersebut, meskipun yang bersangkutan sudah sampai di Indonesia, adalah akibat adanya tekanan dari gerakan anti pembaharuan Islam oleh sejumlah gerakan Islam. ${ }^{3}$

Munculnya gagasan-gasan lama untuk mengembalikan kehidupan umat Islam ke abad-abad yang silam adalah pertanda jelas tantangan pembaharuan dalam Islam itu. ${ }^{4}$ Mengapa semua ini terjadi? Apa penyebab utamanya? Apa kemungkinan akibatnya bagi masa depan Islam yang semakin hari semakin berat tantangan yang dihadapinya? Untuk menjawab pertanyaan-pertanyaan itu barangkali akan lebih baik untuk dibicarakan logika mengapa terjadi benturan dalam lalu lintas pemikiran yang bermuara kepada kelesuan, pemandegan, stagnansi pembaharuan pemikiran saat ini. Seseorang atau sekelompok orang yang mempunyai aktivitas membangun pemikiran dan mengkritisi sebuah wacana tidak ubahnya seperti seseorang yang sedang menggunakan jalan raya (ruang publik). Ada begitu banyak orang yang simpang siur menggunakan jalan raya sesuai dengan asal dan tujuan serta kepentingannya masing-masing. Karena begitu banyak pengguna jalan, maka diperlukan seperangkat aturan atau rambu-rambu atau setidaknya etika, sehingga setiap orang bisa mengguna jalan dengan baik, aman bagi dirinya dan bagi orang lain. Dia

${ }^{1}$ Lihat misalnya opini-opini yang muncul di harian Kompas, Media Indonesia, Republika, dan lain-lain terbitan tiga tahun terakhir ini di bandingkan dengan masa-masa setelah kejatuhan Orde Baru.

${ }^{2}$ Salah satu publikasi dari proceeding annual conference ini lihat misalnya, Direktorat Pendidikan Tinggi Islam, Proceeding the $9^{\text {th }}$ Annual Conference on Islamic Studies 2009, Surakarta: 2009. Meskipun secara umum harus diappresiasi bahwa annual conference ini adalah salah satu upaya wahana bagi pembaharuan pemikiran dalam Islam di Indonesia, akan tetapi dari segi siapa yang diundang untuk berbicara terlihat tidak begitu representative. Karena relatif mereka adalah orangorang yang belum mempunyai reputasi yang luas. Dari sekitar 50 paper yang disajikan, tidak sampai 10 persen pembicaranya yang sudah mempunyai pengaruh di mata akademisi Indonesia.

${ }^{3}$ Lihat misalnya komentar Henri Shalahuddin, "Pembelokan Makna ACIS," dalam http:// insists.multiply.com/., diunduh tanggal 12 Maret 2011.

${ }^{4} \mathrm{Hal}$ ini khususnya apabila dikaitkan dengan gerakan-gerakan anti bid'ah yang menghambat munculnya pemikiran-pemikiran yang mengkritisi pendapat para pemikir (ulama) masa lalu. 
bisa sampai kepada titik yang ditujunya dan orang lain tidak merasa terganggu untuk mencapai titik yang dia tuju baik sama atau berbeda dengan tujuan pengguna jalan lainnya.

Sesungguhnya, untuk berangkat dari satu titik menuju ke titik lain di setiap jengkal bumi dengan menggunakan kendaraan, seseorang harus menggunakan jalan yang juga digunakan oleh orang lain. Pada umumnya, jalan raya yang digunakan oleh publik yang beragam mempunyai peraturan dalam menggunakannya untuk menciptakan keselamatan bagi pengguna jalan itu sendiri. Meskipun jalan yang hanya digunakan oleh kalangan terbatas mungkin tidak diperlukan adanya aturan, karena potensi terjadinya tabrakan tidak terlalu signifikan atau dikhawatirkan, tetapi tetap saja diperlukan etika penggunaan ruang publik. Artinya, peraturan atau rambu-rambu dibuat untuk menghindari adanya pengguna jalan yang mengambil jalur orang lain dengan arah yang berlawanan atau semaunya saja.

Pertama, di setiap negara di dunia ini ada peraturan yang mengharuskan bahwa seorang yang mengendarai kendaraan, baik roda dua atau roda empat dan seterusnya, harus menggunakan lajur sebelah kiri di sejumlah negara dan lajur sebelah kanan di sejumlah negara lainnya. Ketentuan ini berlaku permanen dan bersifat umum, terkecuali dalam kondisi yang sangat darurat. Di negara-negara Eropa dan Australia serta negara yang pernah dijajah oleh Inggris, pengendara menggunakan lajur kiri. Sementara di Amerika, mereka menggunakan lajur kanan. Siapapun yang menggunakan lajur yang berlawanan akan berpotensi kuat menciptakan kecelakaan yang bisa membahayakan dirinya dan orang lain yang berlawanan arah.

Kedua, meskipun seseorang menggunakan lajur yang sama, ketika dia harus mendahului orang lain dengan menggunakan kecepatan yang lebih dari orang yang akan didahuluinya, maka dia harus menggunakan rambu-rambu dengan lampu sign-nya. Ini dilakukan ketika berada pada kondisi jalan yang memungkinkan seperti jalan lurus dan tidak ada pengendara yang berada dari arah yang berlawanan. Pengendara yang ada di depannya harus memberinya jalan selama itu memungkinkan. Tidak ada alasan bagi pengguna jalan yang untuk lamban menghambat dan tidak memberikan ruang bagi pengemudi lain yang ingin sampai lebih cepat ke tempat tujuannya.

Ketiga, meskipun seseorang boleh menggunakan kecepatan tingggi untuk sampai pada tujuan yang ditujunya, pengendara yang bersangkutan tidak boleh menggunakan jalan semaunya, misalnya melebihi kecepatan yang dibolehkan, atau mengemudikan kendaraan dengan zig-zag yang berpotensi kuat terjadinya kecelakaan atau setidaknya mengkhawatirkan orang lain. Karena itu, di setiap negara, ada ketentuan kecepatan tertentu di jalan raya (tol atau high way). Tidak boleh terlalu cepat, karena berpotensi kecelakaan seperti menabrak kendaraan di depannya atau tidak boleh terlalu lambat, karena menghambat orang lain yang ingin lebih cepat. Jika seorang pengemudi tidak bisa menjalankan kendaraannya dengan cepat sesuai aturan kecepatan yang ada di jalan tol, maka pengemudi tersebut dipersilakan menggunakan jalan biasa. 
Keempat, semakin banyak kendaraan, maka jalan yang digunakan juga seharusnya semakin diperlebar atau peraturan penambahan kendaraan yang diperketat. Keduanya ini dilakuan untuk menghindari kemacetan. Akibat langsung dari kemacetan merupakan penghambat orang untuk mempercepat sampainya pengendara pada tujuannya. Sementara akibat tidak langsung munculnya penyakit stress, dan bahkan bisa dimanfaatkan oleh pihak ketiga seperti pelaku kriminal di jalan raya.

Demikian juga halnya dengan aktivitas pemikiran, di mana seseorang yang menyampaikan sebuah wacana, pemikiran atau merespons pemikiran orang lain, sesungguhnya dia sedang menggunakan ruang publik yang juga digunakan oleh orang lain. Seabstrak apapun pemikiran itu, ketika ia memasuki ruang publik karena ia ditulis, dibaca, didengar dan disampaikan oleh atau kepada orang lain, maka ia akan bersentuhan dengan pemikiran orang lain, baik yang sependapat maupun yang tidak sependapat. Ada lalu lintas abstrak ibarat jalan raya tadi. Sesungguhnya, keruwetan arus lalu lintas pemikiran jauh melebihi arus lalu lintas pengguna jalan raya di atas tadi. Karena secara kuantitas, hampir semua orang mempunyai potensi aktif untuk menyampaikan gagasannya. Sementara, kendaraan bermotor di jalan raya hanya dimikili oleh kalangan terbatas saja. Dapat diasumsikan potensi tabrakan pemikiran jauh lebih besar dari pada tabrakan di jalan raya.

Meskipun dengan argumen demokrasi bahwa setiap orang bebas menyatakan pendapatnya, tetapi apabila pendapat itu jelas akan berdampak negatif bagi kehidupan orang banyak, maka penyampaian pendapat seperti itu harus ada etika atau rambu-rambu. Dia juga harus memperhatikan rambu-rambu atau etika menggunakan ruang publik untuk itu. Jika tidak, maka hal yang sama yang tidak diinginkan dengan pengguna jalan di atas juga bisa terjadi, seperti tabrakan pemikiran. Rambu-rambu pengguna ruang publik ini seharusnya adalah rambu yang dibuat bersama dan untuk kepentingan bersama. Bukan rambu yang dibuat sekelompok orang terbatas yang hanya menguntungkan sekelompok orang dan merugikan atau bahkan menakutkan bagi orang lain. Jika orang-orang yang berpotensi baik untuk menyampaikan dan mengembangkan wacana pemkiran dalam rangka memperbaiki kehidupan sosial kemasyarakatan merasa ketakutan menggunakan ruang publik di atas, maka terjadilah kelesuan pemikiran.

Inilah yang terjadi di Indonesia beberapa tahun terakhir. Ada sekelompok orang yang ingin menggunakan dan menyampaikan gagasan pemikiran pembaharuan tanpa batas (semaunya mungkin?) di satu pihak. Ada juga orang yang membuat rambu-rambu dan etika pengguna ruang publik ini semaunya juga. Ada sekelompok orang yang membuat rambu-rambu sendiri, yang tujuan mungkin saja baik, tetapi cara dan rambu-rambu yang dibuat tidak adil, karena merugikan pihak lain. Sebagai contoh adalah penghalalan darah orang tertentu setelah yang terakhir ini menyampaikan gagasan pemikirannya.

Kebebasan seseorang menyampaikan pendapat tanpa batas yang disebutkan di 
sini dalam konsep Isaiah Berlin ${ }^{5}$ disebut dengan negative liberty (kebebasan negatif). Menurut Berlin, ada dua konsep kebebasan yaitu kebebasan positif (positive liberty) dan kebebasan negatif (negative liberty). Negative liberty adalah kebebasan yang dinikmati seseorang untuk melakukan apa saja yang dia kuasa dan inginkan untuk melakukannya, tanpa ada hambatan dan aturan dari orang lain. Ringkasnya, negative liberty adalah kebebasan semaunya untuk berbuat tanpa aturan. Sedangkan positive liberty merupakan kebebasan yang bisa dinikmati seseorang untuk mengekspresikan dirinya dalam berbuat dan menyampaikan pendapat demi kemaslahatan publik dengan mengikuti aturan, sehingga kebebasan ini betul-betul demi kemaslahatan, kebaikan atau kepentingan orang banyak. Ringkasnya, positive liberty adalah kebebasan di mana seseorang bebas untuk memaksimalkan potensi yang ada pada dirinya untuk melakukan sesuatu dengan menggunakan rambu-rambu. ${ }^{6}$

Negative liberty, baik digunakan dalam ruang publik kongkrit seperti jalan raya di atas, maupun dalam ruang publik abstrak seperti pemikiran yang menjadi fokus tulisan ini, sama-sama berpotensi bagi terciptanya tabrakan atau setidaknya ketidaknyamanan publik. Karena itulah perlu ada rambu-rambu atau etika di mana seseorang harus membatasi diri ketika ruang publik yang dia pakai dengan kebebasan yang dia nikmati berpotensi menciptakan ketidaknyamanan bagi pengguna ruang publik lainnya. Meskipun demikian, ini tidak bisa diartikan pembatasan kebebasan berpikir, tetapi lebih tepat dan dapat diartikan sebagai pengaturan lalu lintas ruang berpikir yang dapat diistilahkan dengan ruang bagi positive liberty.

\section{Alternatif Logika Pembaharuan Pemikiran dalam Islam}

Menarik mengutip dua pendapat tokoh berikut. David Dean Commins berkata "return to the Quran and the Sunnah, and understand them as the pious forefathers had. Call Muslims to act according to their religion's teachings. Warn Muslims against polytheism in its various forms. Revive free Islamic thought within the bounds of Islamic principles. Set up an Islamic society and implement God's law on earth." Ziauddin Sardar berkata "all reformist work must start with recognition of the world as it is. We must see and understand the world as it exists and not as we would like it to be. Only when we appreciate the true dimensions of contemporary reality can we contemplate reforms that will create the world we want." 8

Dua kutipan di atas merepresentasikan dua pilihan yang telah dilakukan seorang

${ }^{5}$ Isaiah Berlin, Four Essays on Liberty (Oxford: Oxford University Press: 1969)

${ }^{6}$ Untuk lebih lanjut lihat Isaiah Berlin, Four Essays on Liberty (Oxford: Oxford University Press: 1969); Ian Carter, "Positive and Negative Liberty," The Stanford Encyclopedia of Philosophy (Edisi Spring 2003).

${ }^{7}$ David Dean Commins, Islamic Reform: Politics and Social Change in Late Ottoman Syria (New York, Oxford: Oxford University Press, 1990), h. vii.

${ }^{8}$ Ziauddin Sardar, Islam, Postmodernism and Other Futures: A Ziauddin Sardar Reader (London: Pluto Press, 2003), h. 106. 
pemikir pembaharu dalam Islam. Pilihan pertama apa yang mungkin disebut dengan. Sedangkan dari kutipan kedua dapat disebut reform or Islamisation, therefore, cannot be undertaken in isolation. ${ }^{9}$

Dalam kaitannya dengan arti penting adanya keragaman pemikiran dalam umat Islam, Ziauddin Sardar menyatakan:

Ciri ketiga dunia kita adalah keragaman yang adalah esensi kelangsungan hidup. Bertentangan dengan mitos Darwin, bukan yang terkuat yang bertahan hidup, tetapi mereka yang menggunakan pluralitas berarti. Monokultur mendominasi, mengisolasi, mengasingkan, megurangi dan akhirnya melahirkan diri kematian dengan keseragaman. Analogi ini paling jelas ditunjukkan dalam pertanian: terlalu berat ketergantungan pada tanaman tunggal berakhir di kelaparan; monokultur memiliki masa depan yang terbatas. Namun banyaknya tanaman menghasilkan kelimpahan. Demikian pula, masyarakat plural memiliki kesempatan yang lebih tinggi kelangsungan hidup budaya dan biasanya berkembang. ${ }^{10}$

Cukup jelas apa yang dimaksudkan oleh Sardar di atas, bahwa beragamnya pemikiran dalam sebuah masyarakat akan menyebabkan masyarakat bisa dinamis dan bertahan lama. Karena itu, untuk menjadikan Islam sebagai rah̆mat li al'âlamîn, membuktikan universalitas sistem nilainya, serta menghadapi tantangan globalisasi dan perkembangan ilmu pengetahuan dan tekhnologi yang sekarang bergerak super cepat, maka kontinuitas pembaharuan pemikiran berbagai aspek oleh pemikir dari berbagai latar belakang berbeda dalam Islam adalah sebuah keniscayaan yang tidak boleh ada tawar menawar, harga mati. Segala upaya untuk menggagalkannya dapat dianggap sebagai tindakan yang merusak makna hakiki kehadiran Islam sebagai agama raḥmat li al-âlamîn ini. Ada fakta bahwa sebagian besar masyarakat Muslim berpendidikan rendah adalah kelompok yang sangat rentan menjadi korban dari arus negatif globalisasi. Bagi umat Islam yang masih mementingkan agama sebagai pedoman utama dalam hidupnya, globalisasi bisa menjadi batu ujian yang sangat berat. Karena, melalui arus globalisasi bisa mengalir berbagai budaya yang bisa bertentangan dengan nilai-nilai agama.

Fakta lain adalah legasi sejarah bahwa pada kurun tertentu dari perjalanan sejarah Islam, umat Islam hanyut dalam taklid halal-haram oriented, ketimbang aspek pengembangan pemikiran. Setiap ada persoalan yang muncul masyakat Islam, dibiasakan merespons dengan melihat apa hukumnya, apakah halal atau haram. Bukan pertanyaan seperti mengapa dilakukan seperti yang dilihat, bukan dengan cara lain yang lebih progresif. Adanya periode tertentu dari sejarah Islam yang terlalu menekankan fiqih sebagai jawaban terhadap sebagian besar aspek kehidupan, telah memformat cara pikir umat Islam seperti itu. Di samping itu, tentu saja anggapan pintu ijtihad telah ditutup dan kampanye anti bid'ah adalah faktor

${ }^{9}$ Ibid., h. 107.

${ }^{10}$ Ibid. 
lain yang tidak boleh dianggap kecil tanggungjawabnya terhadap petaka ketertinggalan Islam dari peradaban lain atau mungkin lebih tepat ketertinggalan Muslim dari nilainilai Islami dalam kehidupannya. Kembali mewabahnya gerakan anti pembaharuan di berbagai negara Islam, baik melalui lembaga pendidikan maupun kegiatan-kegiatan dakwah lainnya, jika tidak diimbangi oleh adanya keberanian untuk mengimbanginya, akan bisa berdampak besar bagi kelesuan kemandulan pemikiran dalam Islam. Lambat laun di suatu masa yang akan datang akan bisa memunculkan adanya generasi yang pemikirannya diamputasi, sebagaimana pengalaman sejarah pasca munculnya pendapat bahwa pintu ijtihad telah tertutup.

Akan tetapi, apa saja yang harus diperbaharui, sejauh mana hal itu dapat dilakukan serta bagaimana cara terbaik untuk memperbaharuinya adalah ruang yang amat luas dan mungkin tidak bertepi. Di sinilah sebenarnya, letak batu sandung besar penghambat gerakan pembaharuan pemikiran di dunia Islam, khususnya di Indonesia dewasa ini.

Dalam komunitas umat Islam saat ini, ada bukti yang jelas bahwa di satu pihak ada keinginan luhur untuk memperluas ruang gerak bagi pemikiran Islam demi penyelarasan nilai-nilai Islam dalam kehidupan super Modern ini. Di samping tentu saja dalam rangka menghadapi kelesuan dan kemandulan internal sebagaimana disebutkan di atas. Namun di pihak lain, ada kekhawatiran yang luar biasa bahwa jika pembaharuan pemikiran dijalankan tanpa kendali (partner?), maka ia bisa keluar dari koridor yang mungkin bukan merupakan tujuan gerakan pembaharuan. Sulit untuk disangkal bahwa liberalisasi pemikiran "absolut" telah menjadi salah satu batu sandung besar yang seakan sekarang membuat gerakan pemikiran seperti terhenti. ${ }^{11}$

Namun liberalisasi "absolut" ini pun tidak boleh dijadikan satu-satunya kambing hitam, tanpa adanya pemikiran rigid yang ada pada sudut "absolut" lain, yaitu sikap anti pembaharuan. Hasil pemikiran fiqih, misalnya, sudah dianggap sesuci al-Qur'an, tidak bisa diganggu gugat lagi. Karena itu, tidak boleh dikaji apalagi dikritisi untuk diberi pendapat baru terhadap sebuah masalah yang belum ada jawaban tuntas dalam karya-karya fiqih Klasik. Terlepas dari ketidakmampuan, kemalasan semata atau apakah karena alasan keyakinan tertentu, sikap sebagian ulama dan pemikiran Muslim yang antipati terhadap gagasan pembaharuan adalah kutub lain dari penghambat gerakan pembaharuan saat ini.

Di samping itu, perlu juga dicatat bahwa pada dalam sejumlah perguruan tinggi Islam di Indonesia, seperti UIN, IAIN, STAIN atau universitas Islam lainnya, juga terlihat adanya semacam disorientasi mahasiswa dalam mengambil program Sarjana (S1) Magister (S2) atau program Doktor (S3), yaitu pragamatis dan akademis instan. Tentu saja, harus diakui

${ }^{11}$ Dalam berbagai disuksi mata kuliah "Perkembangan Pemikiran Modern dalam Islam (PPMDI) dengan mahasiswa S2 di PPs IAIN STS Jambi, seringkali muncul kritik bahwa gerakan pemikiran yang mengkritisi keberadaan al-Qur'an atau ayat-ayatnya merupakan gerakan pemikiran "liberalisasi absolut" yang dicurigai untuk mengkritisi Islam itu sendiri, bukan pemahaman atau tafsiran terhadap kita sucinya. 
bahwa problem ini tidak hanya problem perguruan tinggi agama Islam saja. Gelar magister dikejar bukan lagi untuk kepentingan keilmuan, tetapi lebih banyak untuk kepentingan pangkat, jabatan atau status sosial lainnya. Hal ini disebabkan oleh adanya tuntutan supaya para guru atau dosen harus memperoleh sertifikat magister sebagai salah satu syarat untuk meningkatkan karir mengajar mereka. Demikian juga sejumlah calon atau anggota legislatif dan eksekutif yang tujuannya jauh sekali dari kepentingan akademis. Kehadiran mahasiswa pragmatis dan instan ini sungguh telah mengganggu idealisme akademis di sejumlah perguruan tinggi Islam. Selain itu, adanya sebagian dosen berlatar belakang pendidikan Malaysia dan Timur Tengah dengan gagasan salafiyah radikalnya, juga sering menjadi penghambat munculnya gagasan pemikiran pembaharuan, karena dianggap menyimpang dari Islam. Akibatnya, pemikiran pembaharuan tidak lagi menjadi sesuatu yang menarik untuk dilirik. Bahkan mungkin bisa dianggap mereka sebagai suguhan basi yang perlu disingkirkan. Gerakan pembaharuan pemikiran Islam dianggap sebagai bagian dari problem, bukan sebagai solusi terhadap problem yang dihadapi umat.

Sejarah pembaharuan pemikiran di dunia Islam (Arab, Mesir, India, Turki, Iran, Indonesia, Syria dan Tunisia) telah bergulir sejak abad 18 atau awal abad 19. Di tanah Arab ditandai dengan gerakan Muhammad bin 'Abd al-Wahhab dengan semangat pemurnian akidahnya. Gerakan pemurnian ini merupakan respon 'Abd al-Wahhab terhadap realitas umat Islam yang menurutnya bertentangan dengan Islam yang pahaminya. ${ }^{12}$

Kemudian, di Mesir dilanjutkan dengan trio al-Afghanî-Muhammad 'Abduh-Rasyid Ridhâ. Gerakan Pan-Islamisme yang diusung al-Afghanî merupakan responsnya terhadap dominasi Eropa di satu pihak, dan melemahnya persatuan umat Islam di pihak lain. Sementara, 'Abduh mengambil langkah pemurnian yang juga digabungkan dengan pembaharuan sistem pendidikan di Universitas al-Azhar. ${ }^{13} \mathrm{Hal}$ ini bergulir ke berbagai negara Islam lain sampai beberapa dekade belakangan ini. Sebagian dari gerakan pembaharuan ini dapat dikatakan bukanlah bersifar refleksi-inisiatif murni yang muncul atas penggalian terhadap sumber Islam, yakni al-Qur'an.

Di Indonesia, gerakan pembaharuan Islam secara kelembagaan atau organisasi keagamaan sudah dimulai sejak pergantian abad 20 ke abad 21 yang lalu. Salah satu organisasi yang paling berjasa dalam hal ini adalah Muhammadiyah yang didirikan pada tahun 1912 oleh KH. Ahmad Dahlan. Muhammadiyah memulai pembaharuannya dengan mendirikan sekolah-sekolah. Tetapi perkembangan terakhir menunjukkan bahwa peran pemikir muda Muhammadiyah telah memberikan kontribusi yang amat besar bagi pembaharuan pemikiran di Indonesia.

Sedangkan gerakan pembaharuan pemikiran secara perorangan dan signifikan baru dimulai pada pertengahan kedua dari abad ke 20. Nama-nama yang perlu disebutkan

${ }^{12}$ Commins, Islamic Reform, h. 34.

${ }^{13}$ Indira Falk Gesink, Islamic Reform And Conservatism: Al-Azhar And The Evolution of Modern Sunni Islam (London-New York: I.B. Tauris Publishers, 2010). 
di antaranya Harun Nasution, Nurcholish Madjid, Munawir Sjazali, dan Abdurrahman Wahid. ${ }^{14}$ Namun, sesungguhnya gerakan pemikiran yang menjadi pemicu utama gerakan pembaharuan belakangan ini adalah muara dari tragedi 9/11 2002, pengebomam World Trade Center (WTC), yang melenyapkan ribuan masyarakat sipil tidak berdosa. Gerakan Islam teroris telah dianggap satu-satunya yang bertanggungjawab terhadap petaka kemanusiaan itu. Ada paksaan untuk memilih "you are either with us or with our enemy, the terorists" kata George W. Bush. Tentu saja tidak dapat dipungkiri adanya kesadaran kolektif, baik dari luar Islam maupun dari dalam Islam sendiri, bahwa ada persoalan dalam masyarakat Islam dalam memahami dan mengimplementasikan nilai-nilai Islam yang mereka yakini. Mengapa Islam yang salah satu pengertiannya "damai" bisa menjadi begitu brutal?. Islam yang begitu luwes dan lapang, mengapa seringkali dia menjadi begitu rigit dan sempit. Nilai Islam yang universal telah dijadikan mentalitas ghetto-parochialis (mentalitas sempit yang hanya senang berdiskusi dan bergaul dengan komunitas terbatas yang mempunyai gagasan tunggal saja).

Gerakan pemikiran yang diusung oleh sejumlah aktivis pemikiran Islam di Indonesia belakang ini, seperti Islam Progresif, JIL (Jaringan Islam Liberal), the Wahid Institute, JIMM (Jaringan Intelektual Muda Muhammadiyah) dan saudara-saudaranya, berawal dari respons terhadap adanya gerakan-gerakan yang membela Islam dengan mentalitas di atas, setelah kran demokrasi dibuka lebar pasca kejatuhan rezim Soeharto dengan Orde Barunya. Dorongan untuk melakukan gerakan juga diperkuat oleh faktor eksternal, ketika terjadi kritik terhadap Islam pasca tragedi pengeboman World Trade Center 2001 di Amerika. Bahwa masing-masing gerakan ini menggunakan nama dan lembaga yang berbeda adalah persoalan pilihan saja. Dengan kata lain, pendirian gerakan-gerakan pembaharuan ini lebih banyak bersifat reaktif-responsif vis-à-vis reflektif-kontemplatif. Salah satu watak gerakan pemikiran reaktif-responsif adalah mudahnya muncul kejenuhan atau kelambanan, ketika terjadi kurangnya aksi berlawanan atau kurangnya daya respon dari masyarakat luas.

Ketika gerakan pembaharuan pemikiran ini menampakkan dirinya secara terangterangan sebagai respons terhadap mentalitas ghetto dan rigid Islam radikal, maka reaksi balik dengan perlawanan sengit bahkan brutal muncul. Fatwa menghalalkan darah pengusung gerakan pembaharuan adalah bentuk kekesalan yang telah mencapai puncaknya. Contoh yang paling tepat untuk hal ini adalah fatwa yang dikeluarkan oleh pihak yang menghalalkan darah Ulil Absar Abdalla pada tahun 2004. Bentuk kekesalan ini juga ditunjukkan dengan cara penghinaan terhadap pembicara tertentu di ruang publik atau di sejumlah forum ilmiah. Jadi, ada aksi, reaksi serta reaksi kembali. Di sini terlihat relatif jelas bahwa yang terjadi adalah permusuhan akademis (untuk tidak mengatakan permusuhan sesungguhnya),

${ }^{14}$ Dalam pengertian yang lebih luas, sebenarnya ada banyak nama tokoh dan organisasi Islam yang juga memberikan kontribusi penting dalam gerakan pembaharuan pemikiran Islam di Indonesia, namun untuk menyesuaikan dengan tema tulisan ini, maka nama-nama di atas ini dianggap lebih relevan untuk dimasukkan. 
bukan partner akademis. Perlu juga dimasukkan di sini adalah adanya sejumlah Islam yang sesungguhnya tidak mau memikirkan Islam (dengan bertaklid buta terhadap hasil pemikiran ulama Klasik), tetapi selalu memusuhi orang-orang yang berusaha berpikir sesuatu tentang Islam. Mengiringi peristiwa ini, Majelis Ulama Indonesia (MUI) sendiri mengeluarkan fatwa haramnya sejumlah gerakan pembaharuan pemikiran di Indonesia, termasuk apa yang dilakukan oleh Ulil Abshar Abdalla. ${ }^{15}$

Menurut Ziauddin Sardar dalam Islam, Postmodernism and Other Futures: A Ziauddin Sardar Reader, setiap gerakan pembaharuan seharusnya dimulai dengan pengakuan terhadap dunia sebagaimana adanya, tidak sebagaimana yang diinginkan. Hanya dengan merekognisi dimensi sesungguhnya dari realitas kontemporer sebuah masyarakat, barulah seorang pembaharu dapat mengkontemplasikan pembaharuan yang akan menciptakan dunia sebagaimana yang diinginkan. ${ }^{16}$ Meskipun ada kesan agak terlambat, beberapa tema workshop yang pernah dilakukan bisa dilihat sebagai pengakuan terhadap realitas as it is itu. Ini merupakan pertanda adanya kemajuan yang sangat berarti dan sangat penting bagi keberlanjutan gerakan pembaharuan pemikiran Islam di Indonesia.

Secara implisit, diketahui bahwa para pengusung gerakan pembaharuan di Indonesia melalui network LSAF, Yayasan Paramadina, the Wahid Institut, Jaringan Islam Liberal (JIL) dan Rahima, ${ }^{17}$ menyadari adanya problem yang sedang dihadapi oleh gerakan pembaharuan pemikiran Islam di Indonesia. Pertama, kesadaran bahwa gerakan pembaharuan pemikiran Islam di Indonesia sedang mengalami stagnansi. Kedua, perlu ada upaya untuk menjawab pertanyaan mengapa terjadi stagnansi?. Ketiga, langkah atau solusi apa yang dapat dilakukan untuk mengatasi stagnansi itu? Keempat, siapa saja atau jaringan mana saja yang mungkin dapat dilibatkan untuk mencari solusi terhadap problem tersebut? Serta pertanyaan lain sebagai turunan dari pertanyaan-pertanyaan ini.

Bertolak dari pertanyaan-pertanyaan ini, akan dielaborasi lebih lanjut problem-problem yang dihadapi oleh gerakan pembaharuan pemikiran Islam di atas. Problem-problem ini juga berdasarkan pada asumsi bahwa gerakan pembaharuan pemikiran Islam di Indonesia disadari sedang mengalami stagansi atau lebih tepat time out, setelah mendapat tantangan sengit, baik dari gerakan yang berseberangan maupun dari masyarakat luas yang mendukung gerakan yang berseberangan itu. Dari elaborasi ini, tulisan ini juga akan berusaha untuk menawarkan solusi alternatif untuk memecahkan kebekuan gerakan pembaharuan pemikiran di Indonesia.

\footnotetext{
${ }^{15}$ Tentang aksi dan reaksi terhadap fatwa ini, lihat Budhy Munawar-Rachman, Reorientasi Pembaruan Islam: Sekularisme, Liberalisme dan Pluralisme Paradigma Baru Islam Indonesia (Jakarta: Paramadina, 2010), h. 5-12. Buku ini membahas dengan mendalam tentang problem yang dihadapi oleh perkembangan pemikiran Islam dari perspektif pelakunya dalam dekade terakhir di Indonesia.

${ }^{16}$ Sardar, Islam, Postmodernism and Other Futures, h. 106.

${ }^{17}$ Charles Kurzman (ed.). Liberal Islam: A Sourcebook (Oxford and New York: Oxford University Press, 1998).
} 


\section{Berbagai Problem Pembaharuan Pemikiran}

Jika sebuah gerakan pembaharuan diandaikan sebagai obat terhadap sebuah penyakit, maka diagnosa terhadap penyakit apa yang sedang diderita pasien menjadi sangat penting dan harus dilakukan dengan cara akurat. Hal ini dilakukan supaya menghindari mengobatan yang salah terhadap penyakit yang sesungguhnya diderita pasien. Pengakuan terhadap adanya penyakit setelah didiagnosa dan adanya keinginan untuk sembuh merupakan sesuatu yang lebih penting lagi. Dari sinilah titik tolak yang lebih jelas terhadap keberlanjutan pembaharuan pemikiran Islam di Indonesia, yaitu penguraian problemnya dan mendiskusikan serta menindaklanjuti solusi yang mungkin ditawarkan.

\section{Problem Definisi dan Orientasi}

Problem pertama dalam pembaharuan pemikiran di dunia Islam adalah problem definisi kedirian gerakan pembaharuan pemikiran itu sendiri, atau lebih tepatnya batasan wilayah kerja pembaharuan sejauh hubungannya dengan al-Qur'an atau dalam batas tertentu juga sunnah Nabi Muhammad SAW. Maksudnya, terlihat adanya kekaburan antara penafsiran dan mempertanyakan eksistensi dari kedua atau sebagian dari konten sumber sakral dan utama dalam Islam itu. Ada perbedaan yang sangat jelas antara pembaharuan terhadap Islam itu sendiri dengan pembaharuan pemikiran tentang Islam, dalam hal ini penafsiran terhadap al-Qur'an dan sunnah Nabi Muhammad SAW.

Di dunia Barat-Kristen, ketika terjadi kritik keras dari gerakan sekularisme, penafsiran maupun eksistensi sumber dan konten keduanya menjadi sasaran dan wilayah kerjanya, tidak terbatas pada wilayah penafsiran saja. Kemenangan gagasan sekularisme dalam banyak wilayah kehidupan publik tidak lagi hanya menambah sistem nilai gereja yang ada, tetapi menggantinya. Substansi sistem nilai dari Injil dan gereja digantikan dengan sistem nilai sekuler. Gereja, kitab suci dan para gerejawan secara perlahan dimarjinalkan dari kehidupan publik, atau setidaknya distigmatisasi di ruang publik yang menyebabkannya sering lumpuh tidak berkutik lagi.

Sementara, di dalam atau terhadap kedua sumber sakral itu (al-Qur'an dan Hadis) dan apa yang dapat atau harus diperbaharui adalah problem kedua terpenting yang perlu didudukkan dalam rangka memperkecil resistensi dari gerakan anti pembaharuan yang bermuara pada stagnansi tersebut. Dengan teori hudud-nya (keterbatasan), Muhammad Shahrur menghimbau dengan nyaring para intelektual Islam pendukung gerakan pembaharuan untuk membuka ruang penafsiran setiap ayat al-Qur'an dengan mengabaikan istilah ayat-ayat qath'iyyah yang selama ini diyakini oleh sebagian besar mufassir. Semua ayat al-Qur'an terbuka untuk ditafsirkan. Namun pada saat yang sama, Shahrur juga mengingatkan bahwa kerja pembaharuan ini dilakukan dalam batas wilayah penafsiran, bukan menggugat eksistensi teks al-Qur'an. Hal ini tentu sangat bertentangan dengan 
apa yang dilakukan oleh Irsyad Manji dengan The Trouble with Islam-nya. ${ }^{18}$ Manji di sejumlah tempat secara jelas menggugat eksistensi ayat-ayat al-Qur'an. Hal seperti ini juga kelihatannya telah menginspirasi sebagian aktivis pembaharuan pemikiran di Indonesia.

Gerakan-gerakan yang disebutkan terakhir ini lebih tepat disebut sebagai gerakan pembaharuan terhadap "Islam" itu sendiri, karena esensi dari sakralitas Islam terdapat pada kitab sucinya, al-Qur'an. Di sinilah diperlukan diskusi tentang definisi dan batasan pembaharuan ini. Jika yang dikritik adalah keberadaan "Islam" itu sendiri, bukan pemahaman terhadapnya atau terhadap kitab sucinya, maka inilah salah satu faktor munculnya resistensi keras dari sejumlah gerakan dalam Islam. Jika upaya pembaharuan yang dilakukan bertujuan untuk menggantikan Islam dengan "nilai-nilai kebebasan liberal dan sekuler" mutlak, yang bermuara pada menggantikan Islam dengan "sistem," "nilai" atau "keyakinan" lain, ini bukan tujuan dari diskusi dalam tulisan ini.

Problem definisi ini juga bisa dilihat dari perspektif "modernization" versus "revivalization", pembaharuan modernis versus pembaharuan kembali. ${ }^{19}$ Modern reformis lebih banyak diinspirasi oleh Europeanisasi atau Westernisasi murni. Meskipun banyak dinilai yang dibawa gerakan ini dapat dijustifikasi oleh al-Qur'an sebagai huda, namun pelabelan gerakan yang Eurocentrisme atau Westernisme itu sangat sering menjadi persoalan. Pelabelan ini telah menyebabkan pengabaian terhadap substansi pembaharuan dan sangat pentingnya konten gerakan yang dilakukan bagi perbaikan umat Islam secara keseluruhan. Bukankah lebih baik kebebasan tanpa batas itu tidak perlu diberi embel-embel "Islam". Sebab penggunaan Islam bisa merupakan plat form yang membatasi ruang gerak kebebasan berpikir.

Termasuk problem besar dalam definisi ini adalah orientasi atau tujuan gerakan pembaharuan. Sebagian gerakan pembaharuan pemikiran Islam di Indonesia saat ini dapat dikatakan sporadis, responsif dan reaktif, ketika gerakan-gerakan itu secara eksplisit sebagai upaya untuk menjadi lawan tanding dari gerakan radikal dalam Islam. Bahkan lebih problematis lagi, ketika gerakan itu hanya merupakan respons terhadap pemikiran sempit seorang tokoh Islam radikal. Gerakan pembaharuan tidak didasarkan nilai-nilai Islam universal yang berawal dari problem masyarakat Islam dalam konteks lebih luas sebagai warga masyarakat peradaban global. Ringkasnya, sebagian dari gerakan pembaharuan pemikiran di dunia akademis Islam tidak ubahnya seperti hulu sungai tanpa muara. Tidak ada tujuan akhir yang jelas dan secara definitif reachable (dapat terjangkau dan terukur), dapat dicapai dengan cara dalam batas tertentu untuk target-target tertentu.

${ }^{18}$ Irsyad Manji, The Trauble with Islam (Australia: Random House, 2003).

${ }^{19}$ Fazlur Rahman, Revival and Reform in Islam: A Study of Islamic Fundamentalism, edited by Ebrahim Moosa (Oxford: One-world Publications, 2000); John O. Voll, "Renewal and Reform in Islamic History." In Voices of Resurgent Islam, edited by John L. Esposito, 32-47 (New York: Oxford University Press, 1983); Seyyed Vali Reza Nasr, Mawdudi and The Making of Islamic Revivalism (New York dan Oxford: Oxford University Press, 1996); Charles Kurzman, Modernist Islam, 1840-1940: A Sourcebook (Oxford and New York: Oxford University Press, 2002). 


\section{Problem Pendekatan}

Bagaimana cara memperbaharui serta apa tujuan pembaharuan dalam Islam adalah problem berikutnya yang perlu didiskusikan dari waktu ke waktu. Yang lebih diperlukan dalam pembaharuan pemikiran adalah diskusi bukan debat kusir, seperti perebutan pengaruh publik sebelum Pilkada (Pemilihan Kepala Daerah). Diskusi dapat di-follow-up sampai sebuah gagasan dapat menciptakan perubahan sosial lebih luas. Diskusi bisa bermuara pada kesepakatan atau kesalingmengertian antara peserta diskusi. Meskipun tidak harus selalu terjadi kesepakatan. Sebaliknya, debat hampir selalu bermuara pada upaya mempertahankan diri atau apoligistik, ketimbang melihat kebenaran sebuah pemikiran. Pihak yang kalah dan lemah argumen dalam sebuah diskusi bisa saja bergabung dan mendukung argumen yang lebih unggul dan rasional. Sebaliknya, dalam sebuah debat, pihak yang menang bisa mengeliminasi pihak yang kalah sampai pada pengambil-alihan keberpihakan audiens yang tadinya lebih banyak berlaku pasif.

Dalam sebuah perdebatan, pada umumnya yang lebih jernih mengambil kesimpulan adalah pendengar. Sedangkan dalam diskusi, baik partner diskusi maupun pendengar sama-sama bisa mengambil kesimpulan yang jernih. Di samping itu, dalam sebuah debat yang dicari adalah keunggulan sepihak untuk mengalah pihak lain yang bermuara pada ujung yang berbeda. Sedangkan dalam sebuah diskusi, fokus utama adalah mencari titik temu. Meskipun ada kalanya titik temu itu sendiri adalah kesepakatan untuk berbeda pendapat.

Ciri lain dari debat adalah mempunyai keterbatasan waktu apabila sudah ada pihak yang lebih unggul atau memang masing-masing sepakat untuk mengakhiri. Sedang diskusi bisa saja menjadi sebuah serial yang berkembang sesuai dengan kondisi yang diciptakan. Dalam sebuah debat, audiens lebih banyak sebagai pendengar pasif yang bisa terpengaruh untuk mengambil sikap meskipun isu yang diperdebatkan bisa saja merupakan kepentingan mereka. Sedangkan dalam sebuah diskusi, audiens bisa terlihat secara aktif baik topik yang didiskusikan bersentuhan langsung dengan kepentingan mereka atau tidak. Salah satu etika diskusi adalah mengakui keunggulan argumen partner dikusi, apabila didukung oleh argumen dan fakta yang kuat. Hal ini jarang terjadi dalam sebuah perdebatan.

Fenomena debat antara pengusung pembaharuan Islam dan penolaknya dalam wacana pembaharuan pemikiran di Indonesia kelihatannya diilhami oleh apa yang terjadi di sebagian besar negara Barat yang sekarang sekuler ketika mereka dulu mengalahkan argumen Gereja yang menguasai ruang publik. Apa yang terjadi di dunia Barat se yang dapat disaksikan pada hari ini adalah marginalisasi agama dari ruang publik, sampai akhirnya ruang publik hanya diisi oleh sekularisme murni. Agama menjadi sesuatu yang aneh yang seharusnya perlu masuk penangkalan, namun didesak sedemikian rupa, sehingga harus mencari tempat keluar dari wilayahnya.

Jika sebagian besar pendekatan yang digunakan debat disebabkan oleh pengaruh tertentu, baik apa yang terjadi antara pihak Gereja dan sekularis di Barat maupun pengaruh pendekatan Timur Tengah masih dapat ditolerir, maka sebagian dari pendekatan yang 
digunakan di Indonesia tidak jauh beda dari UFC (Ultimate Fighting Championship) yang sering bermuara pada kuncian mati, sehingga pihak yang kalah bertekuk lutut sampai tidak bisa berbuat apa-apa dalam sebuah forum. Padahal seharusnya, tidak ada istilah menang mutlak dalam sebuah pertarungan pemikiran. Karena, kebenaran pemikiran bersifat relatif yang sangat tergantung pada situasi ruang dan waktu.

Stagnasi gerakan pemikiran beberapa tahun terakhir ini bisa dilihat dalam konteks ini, ketika gerakan yang berlawanan mendapat applous yang semakin kuat dan tempat yang semakin luas dalam masyarakat. Jika gerakan pembaharuan pemikiran mendapat giliran ketika vendulum sejarah lebih mendekatinya suatu saat nanti, maka tidak tertutup kemungkinan apa yang dilakukan oleh penentang pembaharuan ini menjadi watak gerakan pembaharuan juga.

\section{Problem Penamaan Gerakan}

Salah satu problem lain yang memperlambat pengaruh pembaharuan pemikiran dan menyempitnya ruang publik yang dapat digunakan adalah pekerjaan rumah yang belum sepenuhnya selesai, yaitu antara substansi dan formalitas. Abdurrahman Wahid (Gus Dur) dan Nurcholish Madjid (Cak Nur) pernah mengingatkan para pengusung Islamis untuk tidak terlalu terfokus pada simbol "Islam" dan mengabaikan substansi. Ajaran moralitas tidak perlu diberi nama apapun, termasuk juga moralitas berbasis Islam, jika ia mau dijadikan moralitas universal. Sebenarnya, jika pengusung gerakan pembaharuan pemikiran bisa mengoreksi diri, maka apa yang diingatkan kedua tokoh pemikir ini terhadap gerakan yang berseberangan dengan "Islamis" juga bisa dijadikan salah satu hal yang perlu direnungkan. Sebagian penyebab munculnya resistensi, seperti dikemukakan di atas adalah kesalahpahaman yang muncul akibat simbol formalitas penamaan gerakan, seperti kata "liberal". Seringkali sesungguhnya, ada substansi yang bisa dijadikan titik temu. Sudah sejak zaman penjajahan dulu, istilah "liberal" menghadapi problem di Indonesia. Meskipun sebagian besar masyarakat Muslim Indonesia yang "terdidik" ada yang sudah dapat mengabaikan nama-nama asing yang bisa diidentikkan apa yang pernah dilakukan penjajah dulu. Seringkali sebuah gerakan dukungan atau penolakan sesungguhnya tidak terlalu besar, tetapi kemudian mendapat dukungan semakin besar dari masyarakat hanya karena hal yang tidak substantif itu, yaitu karena nama yang tidak familiar di tengah masyarakat. Mengapa sejumlah nama jurnal yang menyuarakan suara "liberal," tapi dengan nama lebih ke-Arab-an tidak mendapat penolakan sebesar "liberal" belakangan ini, barangkali adalah contoh terbaik untuk direnungkan.

Siapa saja bisa berargumen bahwa apalah arti sebuah nama. Namun, ketika sebuah nama yang betul-betul merupakan refleksi dari apa yang menjadi spirit dari sebuah gerakan pemikiran, maka sesungguhnya nama itu adalah gerakan itu sendiri. Mengapa sejumlah gerakan pembaharuan dalam Islam menggunakan istilah seperti pembaharuan kembali ke al-Qur'an dan Hadis Nabi Muhammad, seperti yang pernah dilakukan oleh Muhammadiyah, 
padahal tidak jarang juga membawa sistem nilai yang sesungguhnya bermuara dari Barat, tetapi mendapat dukungan luas?.

Jawaban yang dekat adalah karena sedalam-dalam atau sekeras-keras kritik diajukan terhadap sebuah realitas, namun muaranya akan tetap mempertahankan Islam (al-Qur'an dan Hadis Nabi Muhammad SAW.) Yang akan ditinggalkan atau dipinggirkan adalah tafsir atau pemahaman dan praktik keislaman yang diyakini tidak sesuai dengan tujuan utama Islam diturunkan sebagai sebuah agama yang mempunyai misi universal.

\section{Problem Spirit}

Motivasi dan semangat yang melatar belakangi sebuah gerakan atau karya pemikiran pembaharuan bisa dilihat sebagai sebuah pedang bermata dua, bisa berdampak positif dan negatif. Jika seorang pembaharu dilatarbelakangi oleh "paksaan" agenda dari luar, maka ini bisa bermuara pada menyenangkan orang lain dan "dimusuhi" orang Muslim sendiri. Meskipun di sini bisa terjadi perdebatan panjang. Namun, seringkali terlihat kegiatan gerakan pembaharuan ketika motivasi tidak murni kepentingan internal Islam, setidaknya ada alasan untuk dicurigai. Salah contoh bisa dikemukan, ketika sebuah gagasan pembaharuan yang lebih sering disuarakan di hadapan audiens non-Muslim. Pada hal yang perlu diperbaharui adalah realitas yang ada dalam tubuh Islam. Di sinilah sering muncul tuduhan bahwa seolah gerakan pembaharuan merupakan agen luar yang dimasukkan ke Islam, sebuah tuduhan yang tidak selamanya atau belum tentu benar sama sekali.

Problem lain yang bisa diasosiasikan dengan sikap dan karakter ini adalah apa yang disebut Ziauddin Sardar sebagai ghetto mentality, yaitu sebuah mentalitas senang berkumpul dengan orang-orang yang satu gagasan saja tanpa kritik. Ghetto mentality sesungguhnya bukan penyakit dari pengusung Islam radikal saja, tetapi juga secara tidak sadar merupakan mentalitas dari pengusung sejumlah gerakan pembaharuan. Upaya yang dilakukan JL dengan melaksanakan kerjasama dengan berbagai perguruan tinggi untuk diskusi tematis sangat perlu diapresiasi. Namun, hal ini perlu dikembangkan dengan melibatkan gerakan serupa yang lebih luas dengan mengikutsertakan gerakan yang berbeda pada saat yang sama. Ketika animo masyarakat tidak besar terhadap kegiatan ini, maka pertanyaan "mengapa" sangat perlu untuk diajukan, untuk selanjutnya dicari jalan keluarnya melalui self-critics. Tidak malah menyerah dengan kenyataan dan bertahan pada cara yang tadinya tidak mendapat respons baik dari masyarakat, seperti yang terjadi sejak lebih kurang tiga tahun terakhir ini.

\section{Problem Keterbatasan Ruang dan Waktu untuk Gagasan Besar}

Ketidakarifan atau mungkin keterpaksaan penggunaan ruang dan waktu sempit yang tidak seimbang dengan besar atau beratnya gagasan atau isu yang menjadi fokus wacana juga merupakan problem dan penghambat berjalannya pemikiran pembaharuan 
di Indonesia. Seringkali pengusung pemikiran pembaharuan menggunakan ruang yang terbatas, seperti koran, talkshow baik TV maupun radio dan diskusi lepas, dibandingkan dengan penulisan sebuah buku yang "tuntas" ketika mendiskusikan isu-isu berat yang membutuhkan ruang yang memuaskan untuk menuntaskan sebuah topik pembicaraan. Seringkali pengusung pembaharuan pemikiran tidak sepenuhnya menyadari sudah masuk ke dalam skenario kerja jurnalis yang sering lebih mengutamakan popularitas dibandingkan menuntaskan pemahaman.

Salah satu contoh terakhir adalah apa yang dilakukan oleh Teater Hutan Kayu satu hari setelah workshop "Menata Kembali Pembaharuan Pemikiran Islam di Indonesia." Pada diskusi serial JIL ini, Ulil Absar Abdalla menyampaikan papernya dengan judul "Doktrindoktrin yang kurang perlu dalam Islam". Pada dasarnya, apa yang disampaikan Ulil dalam paper (pokok pikiran)-nya itu tidak begitu jauh dengan dengan kampanye anti bid'ah ala gerakan "salafi". Tapi, dasar pemikiran yang disampaikan Ulil yang melandasi pemikirannya itu tidak dimuat dalam pokok pikirannya itu. Padahal, sebelas poin yang disampaikan Ulil adalah isu-isu yang sangat memerlukan landasan pemikiran yang kuat. ${ }^{20}$ Karena itu, sangat perlu disertai dalam pokok pikirannya itu, tidak dimuat secara terpisah. Demikian juga, sejumlah gagasan gerakan pembaharuan pemikiran yang pernah disampaikan Ulil sebelumnya seperti tentang haji, jilbab dan sebagainya. Argumen-argumen yang bersumber dari ayat-ayat al-Qur'an atau Hadis Nabi Muhammad SAW yang sering dijadikan alasan oleh penantang pembaharuan pemikiran dalam Islam sama sekali tidak disentuh oleh Ulil. Sebagai contoh argumen bahwa Nabi Muhammad adalah nabi penutup (khatam al-nabiyyîn) berdasarkan Q.S. al-Ahzzab/33: 40. Sekiranya Ulil bisa membahas lebih jauh tentang tafsiran khatam al-nabiyyîn, maka tentu akan terjadi diskusi dan adu argumen. Ketika Ulil menyatakan kurang perlunya doktrin bahwa Nabi Muhammad adalah Nabi terakhir/penutup dalam Islam, sehingga memungkinkan penganut Islam tertentu, seperti Ahmadiyah, berhak hidup di Indonesia, tidak begitu kuat ketika argumen yang mendukung doktrin ini tidak secara tuntas dijelaskan. Demikian juga doktrin-doktrin lain yang disampaikan oleh Ulil dalam pokok pikirannya tentang "Doktrin yang tidak perlu dalam Islam" itu. Terlalu sempit ruang yang disediakan untuk gagasan atau isu-isu yang sangat penting dan besar itu.

\section{Problem Kelembagaan}

Meskipun masih memerlukan data dan kajian lebih lanjut, namun dari berbagai diskusi lepas dan korespondensi dengan berbagai teman, baik dalam maupun manca negara, dapat dikatakan bahwa faktor kelembagaan merupakan salah satu problem dalam pem-

\footnotetext{
${ }^{20}$ Untuk lebih jelasnya tentang pokok-pokok pemikiran Ulil Abashar ini, lihat "Doktrindoktrin yang Kurang Perlu dalam Islam", disampaikan pada Dikuski serial JIL (Jaringan Islam Leberal", Teather Hutan Kayu, Jakarta tanggal 30 Desember 2010.
} 
baharuan pemikiran di Indonesia. ${ }^{21}$ Pertama, bahwa keberadaan dari sejumlah gerakan pembaharuan pemikiran di Indonesia yang berbasis Lembaga Swadaya Masyarakat (LSM) yang sebagaian besar pendanaan programnya tergantung pada penyandang dana, baik dalam maupun luar negeri, kemungkinan bagian dari penyebab lain tidak stabilnya perjalanan gerakan pembaharuan pemikiran yang dilakukan. Sebagai LSM, setidaknya ada empat faktor yang menentukan perjalanannya; adanya Sumber Daya Manusia, adanya program, adanya dana untuk menjalankan program dan adanya penyandang dana baik yang bersifat permanen maupun yang bersidat indisentil. Terlepas apakah dapat dibuktikan atau tidak, keberadaan sejumlah LSM berlabel Islam yang dibiayai luar negeri atau penyandang dana tertentu dari dalam negeri, sudah lama dicurigai mempunyai tujuan dan agenda yang "dipesan," bukan egenda murni sebagai refleksi dari analisa problem masyarakat. Kedua, keberadaan LSM gerakan pemikiran Islam yang terkadang terlihat kasat mata berhubungan dengan lembaga-lembaga politik praktis juga dianggap bahwa LSM terkait sebenarnya mempunyai kepentingan-kepentingan praktis dan instan. Itulah salah satu sebab lain yang terkadang membuat idealisme gerakan pembaharuannya berjalan tersendat-sendat.

\section{Penutup}

Berdasarkan uraian di atas, maka langkah prioritas dalam menata kembali pembaharuan pemikiran dalam Islam Indonsia sebagai bagian terhadap kontribusi global adalah dengan menjadikan gerakan pembaharuan sebagai gerakan membangun "peradaban masyarakat universal" berbasis nilai-nilai yang bersumber dari Islam. Hal ini dilakukan atas pertimbangan keyakinan universalitas nilai-nilai Islam. Dengan demikian, ghetto mentality yang menyebabkan nilai Islam menjadi sempit, bringas, radikal, termasuk teror fisik maupun mental, dapat dihindari melalui perbaikan agenda dan perubahan pendekatan. Respons-respons sporadis terhadap gerakan yang berseberangan akan lebih baik dialihkan pada perhatian terhadap masyarakat luas, di mana gerakan yang berseberangan seringkali memperoleh dukungan. Menggunakan ruang publik dengan bahasa yang mudah dimengerti oleh publik luas sebagaimana yang digunakan oleh gerakan anti-pembaharuan menjadi hal yang sangat perlu dipertimbangkan kembali. Dalam konteks inilah, kesan elitis gerakan pembaharuan pemikiran di Indonesia harus melihat situasi dan kondisi. Meskipun kesan elit dan arogansi akademis perlu dipertahankan pada saat tertentu, namun ada situasi dan kondisi tertentu di mana gerakan pembaharuan harus menanggalkan keelitisannya.

Namun perlu diingat, bahwa gagasan dan perjalanan globalisasi saat ini hampir tidak memungkinkan adanya satu kontributor tunggal untuk membangun peradaban universal, tidak juga Barat yang sudah sangat maju itu.

${ }^{21}$ Salah satu korespondensi penting dalam tulisan ini adalah dengan Mun'im A. Asirry yang sependapat dalam hal ini. Hal ini didukung oleh perbandingan yang dia buat antara Indonesia dan di Amerika. 
Dalam gagasan membangun peradaban (atau lebih tepatnya meneruskan) bangunan pondasi kemanusian global, maka ada beberapa hal yang harus diperhatikan. Pertama, sifat gerakan yang permanen, terus menerus dan menyeluruh. Artinya, para pengusung dan pejuang pembaharuan pemikiran Islam sangat dituntut untuk mendata problem masyarakat, membangun atau mencari teori untuk mengatasinya, serta melibatkan perorangan atau lembaga tertentu dalam mengatasi problem terkait. Kedua, program dan tema-tema gerakan disesuaikan dengan problem masyarakat yang diperoleh dari hasil penelitian tentang realitas kehidupan masyarakat.

Dalam konteks semua inilah, membangun kerja sama yang "permanen" dengan lembaga perguruan tinggi menjadi sangat penting, dan mungkin niscaya. Lembaga peguruan tinggi adalah lembaga yang harus bertanggung jawab untuk mengantisipasi dan merekayasa perubahan sosial. Rekayasa perubahan sosial ini salah satu titik temu antara gerakan pembaharuan pemikiran Islam yang ada di luar kampus. Namun dalam membangun kerjasama dengan perguruan tinggi, tentu ada persyaratan-persyaratan awal yang harus dipenuhi dan disepakati. Karena bagaimanapun perguruan tinggi tentu dalam hal ini mempunyai posisi bargaining yang lebih besar, karena ia bersifat permanen. Di sinilah perlu untuk diambil langkah-langkah mengantisipasi, menghindari dan mengatasi problem-problem yang disebutkan di atas.

Pekerjaan menata kembali gerakan pembaharuan pemikiran Islam di Indonesia ini tidak mudah, tetapi jika pemikiran adanya stagnansi gerakan pemikiran di Indonesia dibenarkan, dan upaya untuk mengatasinya disepakati, maka pokok-pokok pikiran di atas menjadi sangat perlu dijadikan salah satu pintu masuk mengatasi stagnansi itu.

\section{Pustaka Acuan}

Berlin, Isaiah. Four Essays on Liberty. Oxford: Oxford University Press: 1969.

Carter, Ian. "Positive and Negative Liberty," dalam The Stanford Encyclopedia of Philosophy, Spring 2003.

Commins, David Dean. Islamic Reform: Politics and Social Change in Late Ottoman Syria. New York, Oxford: Oxford University Press, 1990.

Gesink, Indira Falk. Islamic Reform And Conservatism: Al-Azhar And The Evolution of Modern Sunni Islam. London-New York: I.B. Tauris Publishers, 2010.

Kurzman, Charles (ed.). Liberal Islam: A Sourcebook. Oxford and New York: Oxford University Press, 1998.

Kurzman, Charles. Modernist Islam, 1840-1940: A Sourcebook. Oxford and New York: Oxford University Press, 2002.

Nasr, Seyyed Vali Reza. Mawdudi and the Making of Islamic Revivalism. New York dan Oxford: Oxford University Press, 1996. 
Rahman, Fazlur. Revival and Reform in Islam: A Study of Islamic Fundamentalism, edited by Ebrahim Moosa. Oxford: One-world Publications, 2000.

Sardar, Ziauddin. Islam, Postmodernism and Other Futures: A Ziauddin Sardar Reader. London: Pluto Press, 2003.

Shalahuddin, Henri. "Pembelokan Makna ACIS," dalam http://insists.multiply.com/.

Voll, John O. "Renewal and Reform in Islamic History," In John L. Esposito (ed.), Voices of Resurgent Islam. New York: Oxford University Press, 1983. 